\title{
The historian's craft and economics
}

\author{
BRADLEY A. HANSEN* \\ Department of Economics, University of Mary Washington, Fredericksburg, VA, USA \\ MARY ESCHELBACH HANSEN** \\ Department of Economics, American University, Washington, DC, USA
}

\begin{abstract}
History refers both to the past and to the systematic study of the past. Attempts to make a case for history in economics generally emphasize the first definition. There are benefits from increased attention to the past. This paper argues that significant benefits can be gained from increased attention to the systematic study of the past, the historian's craft. The essence of the historian's craft is the critical evaluation of sources. Failure to critically evaluate sources has the potential to lead to erroneous conclusions, whether one is using historical documents or more recently created data.
\end{abstract}

\section{The historian's craft and economics}

Many advocates for the reform of economics as a discipline argue that economists need to give more attention to history. They argue that inadequate attention to history has left economists ill-prepared to understand fundamental economic problems of growth, distribution, and stability (Boettke et al., 2013; Eichengreen, 2015; Hodgson, 2001 and 2009; Nunn, 2009; O’Rourke, 2013; Peterson, 2013; Piketty, 2014; Shiller, 2010). But what does it mean to give more attention to history? The historian Hexter (1971: 15) noted that the term history has two meanings: it is used 'to identify both the past and the systematic study of it'.

Most of the arguments for increased attention to history have emphasized the benefits of increased attention to the past, rather than the benefits of increased attention to the systematic study of the past. For example, McCloskey (1976) claimed that looking to the past could provide economists with more and better data: history expanded the economist's laboratory, offering access to experiments that would ultimately lead to better theory, better policy, and better economists. New institutional economists have argued that the importance of history extends beyond providing an expanded laboratory to test economic theories. These arguments often build on some form of path dependence to argue that a current institutional framework can only be understood as the result of its historical evolution (Boettke et al., 2008 and 2013; North, 1981; Nunn, 2009).

*Email: bhansen@umw.edu

**Email: mhansen@american.edu 
While institutional economists have generally been advocates for an expanded role for history in economics, some economic historians have recently raised concerns about the way economists have incorporated the past into their work. Temin (2014), for instance, argues that although Acemoglu and Robinson (2013) devote considerable attention to the past, their book is not good economic history because they pluck examples that support their argument and ignore contradictory information. Ogilvie and Carus (2014) question a number of stylized facts about economic history that have figured prominently in the analysis of the emergence and evolution of institutions. Van Bavel (2015) argues that economists' attempts to explain long run growth often lack-historical depth, placing too much emphasis on the role of the nation-state and the industrial revolution while giving too little attention to social factors. Overall, these authors suggest that the task of incorporating the past into economics is not an easy one and that a greater understanding of history could lead to greater insights about institutional change. They advocate wider reading in history, leading both to more familiarity with the varieties of historical experience within and between nations, and to more knowledge of the controversies among historians.

We concur that a more careful reading of historians' work is warranted, but we stress that economists, and others, interested in institutions should also give more attention to the systematic study of the past, particularly the critical evaluation and interpretation of sources. Moreover, we argue that greater attention to the critical evaluation and interpretation of sources - what Bloch (1953) called 'the historian's craft' - is not just essential for attempts to incorporate history into economic analysis, but it is beneficial for all empirical work.

To illustrate the importance of the historian's craft, we show how three attempts to incorporate the past into the analysis of institutions evolved as successive authors gave increased attention to the critical evaluation of sources. In addition, we show that the analysis of evidence collected by modern researchers through experiments and surveys requires skills in critical evaluation because these sources have the potential to be as biased, inaccurate, and misleading as historians' archival documents.

\section{The historian's craft: critical evaluation of sources}

There is no universally accepted definition or description of the historian's craft. There is however, a large literature on historical methods (for example, Appleby and Hunt, 1994; Bloch, 1953; Burke, 1993; Cipolla, 1992; Elton, 1983; Evans, 1999; Fogel, 1983; Gaddis, 2002; Ginzburg, 2013; Hexter, 1971; Hoffer, 2008; Megill, 2007; Nevins, 1962; Winks, 1968), and there are textbooks that introduce both undergraduate and graduate students of history to widelyaccepted approaches to good research (Brundage, 2013; Davidson and Lytle, 2009; Dobson and Ziemann, 2009; Howell and Prevenier, 2001; Marius and Page, 2002). Historians study a wide array of topics and employ a wide array of 
techniques. Nevertheless, we argue a unifying theme underlies the application of these diverse techniques. The unifying theme is the critical evaluation of sources.

The development of source criticism went hand-in-hand with the development of history as a distinct discipline and the development of historian as a distinct profession (Appleby and Hunt, 1994; Hoffer, 2008; Novick, 1988). In a popular text on historical methods, Howell and Prevenier (2001: 3) claim that the central tenet of the discipline of history is that 'critical engagement with the records of the past can produce useful knowledge about the past'. These records of the past include the sort of archival documents (such as, letters, diaries, and company records) that people typically associate with historical research, but they also include material objects (such as, structures, clothing, and coins). Bloch, for instance, was one of the pioneers in the use of non-traditional sources, using, for example, aerial photographs to try to better understand medieval agriculture (Dobson and Ziemann, 2009: 4). Historians continue to introduce new types of sources, using, for example, the study of tree rings to better understand environmental conditions during early American settlement (Blanton, 2000).

Sources are the historian's fundamental constraint; they constitute the available evidence of what happened (Gaddis, 2002: 43; Megill, 2007: 76). Sources are, however, imperfect and incomplete; indeed, they are sometimes contradictory. Because historians must create interpretations of the past that are consistent with the bits and pieces of evidence that survive, they question and challenge each source (Howell and Prevenier, 2001: 60-68; Marius and Page, 2002: 39-47). How, they ask, did this come to exist and why has it been preserved? Is it authentic or a forgery? If it is authentic, was the person who created it in a position to produce an accurate record? Did the person have any incentive to lie? Did the person have any incentive to tell the truth? What biases did the person have that may have influenced what was recorded?

One of the most important elements of source criticism is evaluating the extent to which a source is consistent with, or can at least be reconciled with, other sources. 'We need not only evidence', Megill argues, 'but evidence of evidence: or to put the matter differently, we need concurrence among different pieces of evidence and forms of evidence' (Megill, 2007: 76). Bloch notes that 'for a piece of evidence to be recognized as authentic, method demands that it show a certain correspondence to the allied evidence' (Bloch, 1953: 120). Although determining authenticity was traditionally one of the central roles of source criticism, modern treatments of historical methods tend to emphasize that the critical evaluation of sources goes beyond simply assessing authenticity. In fact, the concept of authenticity is recognized as being somewhat ambiguous: 'The false or inauthentic nature of a source lies not so much in its material qualities as in the intention of its creator and the uses to which it is put' (Howell and Prevenier, 2001: 58). Moreover, even a source that was intended to be an objective account ultimately reflects reality as its creator perceived it. Consequently, historians do not so much seek to determine the authenticity of 
a source as to 'derive the significance of a source by placing it in context - that is, comparing it with other similar sources or different sources produced at the same time period, much as an archeologist judges an artifact by where it lies in the sediment' (Lipartito, 2014: 288). Historians also need to clearly document their sources so that others can follow the same trail of evidence (Lipartito, 2014: 301). Thus, the historian's craft has three parts: a diligent search for sources, critical evaluation of the sources, and clear documentation of each source.

Training in history does not guarantee that sources will be examined critically and presented accurately, but 'historians have traditionally judged the quality of their own or their colleagues' work in terms of mastery of these skills' (Howell and Prevenier, 2001: 2). Moreover, many historians continue to reserve their harshest criticism for those who are believed to have misused sources (Evans, 1999: 100-106; Hoffer, 2004). Responses to recent work by historians on the state of the historical discipline (Guldi and Armitage, 2014) and the role of slavery in American economic history (Baptist, 2014) suggest that perceived misuse of sources can still prompt a strong response (on Guldi and Armitage see Cohen and Mandler, 2015; Koyama, 2015; on Baptist see Burnard, 2015; Feller, 2015).

There is, of course, more to historical methods than the critical evaluation of sources. Collingwood (1946), for instance, emphasizes the role of historical imagination. Hexter (1971) emphasizes the narrative method of explanation as a central element. But critical evaluation of sources precedes both imagining and narrating the past. To Bloch source criticism is more than the essence of the modern historian's craft, it is a gift that historians give to the world. 'It is a scandal', he lamented in the 1940s, 'that in our own age, which is more than ever exposed to the poisons of fraud and false rumor, the critical method is so completely absent from our school programs'. But '[h]enceforth', he declared, 'far wider horizons open before it, and history may reckon among its most certain glories that, by the elaboration of its technique, it has pioneered for mankind a new path to truth and, hence, to justice' (Bloch, 1953: 137). Perhaps Bloch's declaration was premature.

Although Bloch suggests that the historian's craft can lead us to the truth, it cannot produce certainty (Megill, 2007: 128). Appleby and Hunt (1994: $234)$ note that 'no one argues any longer... that historical narrative in any way exactly mirrors past reality as it actually was'. A full exploration of the epistemology of historical knowledge is beyond the scope of this paper. Nevertheless, we argue that careful practice of the historian's craft can lead to more persuasive arguments and a greater degree of confidence in our knowledge.

The study of argument (rhetoric) reminds each researcher that persuasion requires him to present reliable evidence and a logically consistent argument - a theory - connecting the evidence to the claim (Toulmin, 2003). In his book on doing economic history, Cipolla (1992) reminds his peers of the correspondence between the requirements of rhetoric and the social scientific method. Cipolla 
suggests that economists tend to do well at developing logically consistent theories but not so well at critically evaluating evidence. On the other hand, historians tend to be weak on theory but strong on the critical evaluation of evidence. It would be better for the study of economic history if everyone paid attention to both the logical consistency of theories and the reliability of data. In other words, the historian's craft is a necessary complement to the social scientific approach, not a substitute for it.

The next section considers three cases in which scholars attempted to incorporate the past into the study of institutions without careful attention to the historian's craft. The first case comes from the branch of new institutional economics that has focused on the theory of the firm and the evolution of business organizations. The second case comes from the branch of new institutional that focuses on the evolution of the 'rules of the game'. The third case focuses on the role of the state in long term economic growth.

\section{Incorporating the past without incorporating the historian's craft}

To illustrate the perils of the uncritical use of sources we examine the study of the merger of General Motors and Fisher Body, the study of the evolution of corporate reorganization, and the study of the relationship between absolutist states, taxation, and economic growth. In each case an influential analysis of institutional emergence and evolution was developed, but the initial work cited few primary sources and provided no discussion of their reliability. In each case subsequent critical evaluation of primary sources undermined the original factual claims and led to substantially different interpretations.

\section{The GM-Fisher body merger}

The merger of General Motors and Fisher Body has been widely used to illustrate how the potential holdup problem arising from asset specificity can influence the organization of firms (see, for example, Cabral, 2000: 41; Milgrom and Roberts, 1992: 137). In 1919, General Motors purchased a 60 percent interest in Fisher Body and entered into a ten-year exclusive contract for Fisher to provide automobile bodies to GM. At the time, Fisher was the leading manufacturer of auto bodies, and the Fisher brothers were regarded as the leading experts in body manufacture. In 1926, although the long-term contract was still in effect, the two companies merged.

In the 1950s, the federal government argued that the merger was one of a number of anticompetitive activities undertaken by E. I. Du Pont de Nemours and Company. Du Pont owned a significant share of General Motors, and the government argued that after the merger Fisher was forced to buy inputs from Du Pont (Manne, 1958). On the other hand, in My Years with General Motors, Alfred P. Sloan claimed that the companies merged because 'there were operating economies to be gained by co-ordinating body and chassis assemblies, and with 
closed body becoming dominant in the industry, it seemed sensible to bring the body operation entirely under the General Motors roof. And it was felt desirable also to bring the Fisher brothers into closer relationship with the organization' (Sloan, 1963: 161). In their study of the life and work of Pierre Du Pont (president of GM from 1920 to 1923 and chairman of the board from 1923 to 1929), Chandler and Salsbury repeated Sloan's explanation (Chandler and Salsbury, 1971: 575). These interpretations cannot be regarded as entirely independent because Chandler had some involvement with both books (McKenna, 2006). Nevertheless, their emphasis on co-ordination and bringing the Fishers into GM are consistent with the Annual Statement of General Motors at the time of the merger, which touted the ability to lower costs through increased coordination and declared that 'of even greater importance is the bringing into closer relationship the Fisher brothers' (General Motors Corporation, 1927: 10).

Klein et al., (1978) offered an alternative theory of the merger that built on the work of Coase (1937) and Williamson (1971). Following Coase, they argued that the merger was intended to lower transaction costs. Following Williamson, they argued that the source of these transaction costs was the potential for opportunistic behavior, or holdup, created by asset-specific investments. Specifically, they argued that Fisher had to invest in equipment that was specific to GM body designs. Because this equipment had little or no value in alternative uses, Fisher was vulnerable to post-contractual opportunism by GM: GM might have forced Fisher to accept lower prices once the investments had been made. GM agreed to the ten-year contract that required that it purchase bodies from Fisher at cost-plus-17.6-percent. The agreement worked well at first, but after a rapid increase in demand for closed bodies, 'Fisher effectively held up General Motors by adopting a relatively inefficient, highly labor-intensive technology and by refusing to locate body-producing plants adjacent to general Motors assembly plant' (Klein, 1988: 202). Vertical integration solved the holdup problem.

In 1987, at a conference honoring the fiftieth anniversary of 'The Nature of the Firm', Coase questioned the generality of holdup as a cause of vertical integration (Coase, 1988). He claimed that he had considered the possibility of opportunistic behavior due to asset specificity, but he had dismissed it as a common cause of high transaction costs because his study of contracts and his conversations with managers had convinced him that contracts and reputation effects were sufficient to prevent holdup. While Klein did not present a reply to Coase during the conference, he published one that reiterated his position (Klein, 1988). Klein's response prompted Coase, with the assistance of Richard Brooks, to investigate the evidence related to the merger. Coase published the results in 2000. Several other scholars also re-examined the GM-Fisher merger and published their findings in 2000 (Casadesus-Masanell and Spulber, 2000; Freeland, 2000; Helper et al., 2000).

The key factual claims in Klein et al. (1978) and Klein (1988) are that Fisher had to make relationship specific investments, that Fisher refused to locate 
body plants adjacent to assembly plants, and that Fisher employed inefficient production processes. The evidence presented in support of these claims is the 1919 agreement as it appeared in the minutes of the Board of Directors of Fisher Body Corporation for November 7, 1919, and evidence provided by GM, especially the testimony of Alfred P. Sloan, in the government's antitrust case against Du Pont. Neither Klein et al. (1978) nor Klein (1988) discuss of the reliability of this evidence; they do not describe any attempts to ascertain the extent to which this evidence is consistent with other available evidence; and they do not reconcile their interpretations with the alternative interpretations in Sloan (1963) and Chandler and Salsbury (1971).

The testimony of Sloan is central to the holdup interpretation, but traditional historical source criticism raises several questions about it. First, Sloan's testimony was given more than two decades after the merger. In general, evidence that is created closer in time to the events is regarded by historians as more reliable than accounts that are recalled years later. Second, Sloan's testimony is subject to alternative interpretations. Sloan testified that the Fisher brothers 'rather questioned the desirability of their putting up large amounts of capital to establish these assembly plants in conjunction with GM assembly plants' (as quoted in Klein, 2007: 12). While Klein interprets the statement as a conflict over the location of plants, others interpreted it as a conflict over the finance of the plants (Coase, 2000; Freeland, 2000). Consequently, source criticism suggests that a variety of independent sources be presented, allowing an evaluation of the extent to which sources either support or contradict each other and an assessment of the degree of confidence to be placed in each. In this particular case, the passage of time and the ambiguity of the statements further emphasize the need for additional sources. Sources that provide direct evidence on the investments made by Fisher, the location of plants, and the technology employed in producing bodies would be desirable.

Coase and the other critics of the Klein-Crawford-Alchian interpretation of the merger use a wide array of primary and secondary sources. In addition to making more extensive use of the testimony and exhibits in the Du Pont antitrust trial, they use the correspondences of Pierre Du Pont, General Motors Annual Reports, and the original 1919 contract between GM and Fisher Body (which differed in important respects to the version published in the Fisher Board minutes), and plant location. Evidence from these sources undermines the central factual claims in Klein et al. (1978) and Klein (1988).

Fisher did not make extensive investments in relationship-specific tools and dies in order to manufacture steel closed bodies for GM. In the 1920s, Fisher bodies were still largely made of wood and used flexible, not relationship-specific, production processes (Casadesus-Masanell and Spulber, 2000: 85). In addition, the contract between Fisher Body and GM required GM to pay for any specialized tools and dies that Fisher needed to produce bodies for it. Fisher Body did not refuse to locate plants close to GM production facilities. Coase (2000: 27); 
Helper, et al. (2000: 453); and Casadesus-Masanell and Spulber (2000: 84) examine plant locations and find that Fisher Body plants were constructed in close proximity to GM assembly plants. Finally, the contract between Fisher and GM required that Fisher use the most efficient means of production (Coase, 2006: 266).

The authors that re-examined the GM-Fisher Body merger concluded that there is considerable evidence supporting the interpretation suggested by Sloan and by Chandler and Salsbury: GM merged with Fisher Body to improve coordination and bring the Fisher brothers more fully into the management of GM (Casadesus-Masanell and Spulber, 2000: 69; Coase, 2006: 274; Freeland, 2000: 48; Helper et al., 2000: 458). Correspondence between Pierre and Lammot $\mathrm{Du}$ Pont indicates that discussions of merger began as early as 1922 , before the holdup problems are supposed to have taken place (Casadesus-Masanell and Spulber, 2000: 82). The merger was the culmination of a process of incorporating the Fisher brothers into the management of GM. Fred Fisher joined the GM Executive Committee in 1922 and the Finance Committee in 1924; Charles Fisher and Lawrence Fisher joined the GM executive committee in 1924; and Lawrence Fisher was made head of the Cadillac division in 1925. Testimony at the anti-trust trial suggests that before 1924 the Fisher brothers were already evenly split, with three devoting most of their time to GM and three devoting most of their time to Fisher Body; it was even suggested that one of the concerns leading to merger was the prevention of potential conflicts among the brothers (United States v. E.I. Du Pont 126 F. Supp. 235: 283).

Klein concedes that 'we know that Fisher Body did not mis-locate any of its plants at the time. We also know that the Fisher Body-General Motors contract included a term designed to prevent Fisher Body from adopting inefficient low capital intensive production' (Klein, 2007: 2-3), but he continues to defend the original thesis that the 1926 merger was an attempt to lower transaction costs that arose from post-contractual opportunism (Klein, 2007, 2008). He argues that in 1922 Fisher Body used the strength of its bargaining position, which came from the rapidly increasing demand for closed bodies and the requirement that GM buy bodies from Fisher, to negotiate the deal requiring GM to bear much of the cost of constructing new Fisher Body plants adjacent to GM assembly plants. Fisher Body's ability to obtain this favorable deal is, in Klein's view, an example of post-contractual opportunism and the primary force behind the merger.

Even if one is persuaded by Klein's revised argument, it is clear that the original and oft-repeated story about Fisher holding up GM by refusing to locate plants near GM assembly plants and employing inefficient production technologies is not correct. The theory that mergers are often the result of holdup due to asset specificity is not supported by the GM-Fisher Body example. Instead, the weight of the evidence in this example supports the theory of merger that Alfred Chandler emphasized: vertical integration enhances co-ordination (Chandler, 1984). 
The merger of Fisher Body and General Motors illustrates the hazards of attempting to incorporate the past without sufficient attention to source criticism. The story has gone from being one of the most widely-accepted uses of history in management and organization studies to one of the most contested. In this regard, the case of the Wabash receivership and its role in the evolution of corporate finance and reorganization is similar.

\section{The wabash receivership}

In 1884, the owners and managers of the Wabash, St. Louis and Pacific Railway had the railroad placed in receivership and a member of the board of directors appointed as receiver. The corporation was reorganized during this receivership. Several authors argue that the receivership of the Wabash marked a turning point in the legal conception of corporations and that it established management control, rather than creditor control, over corporate reorganization in the U.S. (Berk, 1994; Franks and Sussman, 2005; Martin, 1974; Perrow, 2002; Roy, 1997). According to Roy, 'There had been no precedent for receivers to be appointed to a railroad not in default or for managers to be appointed receivers. The prevailing doctrine gave control to creditors and held managers responsible for bankruptcy. The Wabash decision set a precedent by which creditors were stripped of many rights in receivership and the courts gave management the right to reorganize the business under the doctrine that the corporation itself was an entity to be preserved' (Roy, 1997: 108). Roy makes this interpretation of the Wabash receivership part of a larger argument 'that the corporation grew into its modern form less by efficiently adapting to the demands of technological development and the growth of markets, than by politically, by the exercise of power' (Roy, 1997: 446).

The key factual claims of this interpretation of the Wabash receivership are that the railroad was placed in receivership even though it was not yet in default, that directors of the firm rather than its bondholders asked for the appointment of a receiver, that a member of the board of directors was appointed as the receiver, and that all of these features of the receivership were novel and deprived bondholders of valuable rights.

Roy (1997: 108-109) relies on Berk's (1994) analysis of the Wabash receivership. Berk's (1994: 51-60) interpretation parallels that of Martin (1974). Both Martin and Berk cite the statements of 19th century legal scholars as evidence that the Wabash receivership was unprecedented. The most prominent source is a Harvard Law Review paper by Chamberlain (1896), which criticized the 'New Fashioned Receivership'. Both Martin and Berk note that Chamberlain had been one of the attorneys who opposed the Wabash receivership when it came before the Supreme Court. They treat this information as an indicator of Chamberlain's knowledge of the case. From the standpoint of historical source criticism, Chamberlain's position as opposing council raises red flags regarding the status of his paper as unbiased evidence. Chamberlain was in a position to 
witness the events, but he also had personal views that could have interfered with his ability or willingness to report them accurately. Consequently, source criticism requires that Chamberlain's views be confronted with other evidence in order to ascertain their reliability.

The evidence provided in support of Chamberlain's views is a legal treatise, published in 1894, and several law review articles from the 1880s and 1890s. However, the opinions of legal scholars - even several of them - cannot be considered dispositive as regards the degree to which the Wabash receivership was an institutional revolution that deprived bondholders of their rights. By the time Chamberlain's article appeared the case had been upheld through several appeals. Other jurists and legal scholars held opposing views. The differing opinions must be acknowledged and evaluated for their consistency with other sources. One set of relevant sources include court decisions before and after the Wabash receivership. Had courts appointed receivers at the request of railroad owners prior to 1884 ? Had courts appointed members of the management as receivers prior to 1884 ? A second set of sources is the record of bond prices. Bond prices are a useful source because economic theory suggests that they will reveal the effect of the receivership on bondholders own valuation of changes in their rights. Are changes in the price of railroad bonds consistent with the claim that bondholders had been deprived of important rights? Evidence on each of these points is inconsistent with claims that the Wabash case was a turning point in the development of railroad receiverships and in the evolution of corporation law.

The Wabash case was not the first time that managers of a railroad asked a court to appoint a receiver because of impending insolvency (Hansen, 2000: 386). In 1845, a Georgia court appointed a receiver in response to a request filed by the owners of the Munroe Railway. During the receivership the railroad was reorganized as the Macon and Western Railway. One of the creditors challenged the receivership, but the Supreme Court of Georgia upheld the lower court's actions, declaring that the appointment of the receiver had protected both 'the rights and interests of the creditors as well as the objects and intentions of the Legislature in granting this charter' (Macon and Western Railway Company $v$. Parker 9 Ga. 377). In the view of the Supreme Court of Georgia, the essence of the receivership was that it protected the rights of all interested parties, and it mattered little who sought the appointment. The decision in the Macon and Western Railway case was not an anomaly. The decision was cited by later courts as well as treatises on railway law (Hansen, 2000: 387).

The Wabash case was also not the first instance in which a court appointed one of the officers of the corporation as receiver. Judges routinely appointed company insiders as receivers. In the ten-years preceding the Wabash case, the presidents of the Erie, the Northern Pacific, and the Philadelphia and Reading were all appointed as receivers over their insolvent railroads (Hansen, 2000: 389; Swain, 1898: 71). These were important railroad corporations, and it seems unlikely 
that anyone interested in railroad finance would have been unaware of their receiverships.

Finally, evidence on railroad bond prices is inconsistent with the traditional argument that the Wabash receivership was either an institutional innovation or that it deprived railroad bondholders of their rights. Economic theory suggests that if part of the value is stripped from an asset, the price of the asset should fall. If the Wabash receivership was truly unprecedented and creditors were stripped of rights, the price of railroad bonds should have fallen. If, on the other hand, the features of the Wabash receivership were not unprecedented, bondholders would have been aware of them when they purchased their bonds, and the case would not have negatively affected railroad bond prices. Railroad bond prices did not fall after the decision; they rose (Hansen, 2000: 402-403). D.H. Chamberlain was not happy with the outcome of the Wabash case, but the evidence shows that it was not an innovation but established practice. This element of the Wabash case illustrates the complementarity between the use of economic theory and the critical evaluation of evidence as emphasized by Cipolla (1992). Theory and evidence are not independent of each other: new theories can lead to new evidence and new evidence can lead to new theories.

As with the Fisher Body-GM merger case, a critical approach to the evidence leads to a substantially different interpretation of the Wabash receivership. Instead of representing a fundamental change in creditors' rights and redistribution of power towards management, the evidence from earlier and later court decisions indicates that the driving force behind the procedures for railroad receivership appears to have been long-held judicial concern with protecting the public interest (Hansen, 2009: 95-128). Because railroads were considered quasi-public, they had options in receivership that other corporations did not (Cohen, 2010: 48; Hansen, 2000: 398).

\section{Absolutism, taxation and economic growth}

The rapacious taxation of absolutist states has been used to explain why modern economic growth emerged first in nations with representative governments such as England. According to Olson, 'There is no lack of historical examples in which autocrats for their own political and military purposes collected as much revenue as they possibly could' (Olson, 1993: 570). Olson offers The Bourbon kings of France and the Hapsburgs of Spain as examples. Similarly, absolutist regimes in China, India, and the Ottoman Empire have been accused of overtaxing compared to regimes in the West. According to Landes (2006:6) one of the primary reasons that China did not experience an industrial revolution was that its government was revenue-hungry: 'the story of the goose that laid the golden eggs is a leitmotif of Chinese history'. Jones concurs that the Chinese empire was, 'an Asian revenue pump' and that 'any notion of an implicit social contract in which services of material consequence were supplied by the emperor in return for his share of national product are spurious' (Jones, 1981: 206). It 
was not just China. In India 'confiscatory taxation meant that few could hang onto much of any productive increase they did create' (Jones, 1981: 62).

DeLong and Shleifer make one of the most explicit arguments about absolutism, taxation, and growth. They find that between the years 1500 and 1800 cities grew more rapidly in states that were classified as limited than they did in states that were classified as absolutist. They conclude that 'limited governments allow faster city growth because they tend to impose lower and less destructive tax rates' (De Long and Shleifer, 1993: 699). De Long and Shleifer do present evidence that between the years 1500 and 1800 cities grew more rapidly in states that were classified as limited than they did in states that were classified as absolutist. They do not, however, provide any direct evidence for the claim that absolutist states imposed higher and more destructive taxes. They, instead, provide references to the work of other scholars. They trace the argument back to observations by Montesquieu and Smith, and they cite North and Thomas (1973), North (1981), Olson (1991), and Brennan and Buchanan (1980). But they do not interrogate these sources. They do not examine the quotations by Smith and Montesquieu in the wider context of each author's work, they do not question the evidence underlying the claims in secondary sources that they cite, and they do not confront their sources with other evidence regarding relative tax rates.

De Long and Shleifer quote Montesquieu and Smith on the harmful effects of insecure property rights and on their shared belief that property rights are more insecure under absolutist regimes. However, De Long and Schleifer do not consider the passages in which Montesquieu and Smith addressed tax rates directly. While Montesquieu believed that absolutist states would be poorer, he didn't believe they would tax more. In fact, he believed that absolutist states would have to tax less: 'General Rule: One can levy higher taxes in proportion to the liberty of the subjects and one is forced to moderate them insofar as servitude increases' (Montesquieu, 1989: 220). He claimed that the relationship was observable within Europe, with England and Holland at one end of the spectrum and Turkey at the other. Smith did not rely only on logic or casual observation; he examined the evidence available to him on tax rates and revenue. He concluded that in 1765 and 1766 the revenue of France was 'not the half of what might have been expected, had the people contributed in the same proportion to their numbers as the people of Great Britain' (Smith, 1976, Book V, CH II: 438). He also concluded that people in Holland were even more heavily taxed than those in Great Britain. Montesquieu and Smith held views of absolutism and tax rates that were exactly the opposite of those suggested by De Long and Shleifer.

None of the more recent authors cited by DeLong and Shleifer provide direct evidence on tax rates. North and Thomas (1973) and North (1981) cite Nef (1957), and Nef provides a direct comparison of tax rates between France and England. He concluded that 'toward the end of his reign, Louis XIII was 
collecting much more revenue for each of his subjects than Charles I- probably between three and four times as much' (Nef, 1957: 128). Nef's analysis was, however, limited to two countries, England and France, and restricted to the years from 1540 to 1640 . His specific estimate applied only to the end of Louis XIII's reign. The evidence Nef cited provides reasonable support for his specific claims about the two countries at a point in time, but it provides a rather weak foundation for general claims about absolutist governments prior to industrialization.

This foundation was particularly weak because other evidence, which contradicted the contention that absolutist states taxed at higher rates than other states was readily available. Mathias and O'Brien (1976), who are not cited by De Long and Shleiffer, challenged the belief that the French were taxed more heavily than the British. They noted that it was not difficult to find descriptions of oppressive French taxation, but rather than taking these complaints about French taxes at face value they examined the available evidence on revenue collected. The task of comparing the tax burden over time in even two countries requires sifting through a large number of sources. Mathias and O'Brien had to estimate the amount of revenue collected and to make the amounts comparable by expressing revenue as a percentage of total commodity output and in terms of the amount of wheat it would purchase per capita. In a nine-page appendix they describe their sources, how they used them, and their strengths and weaknesses. They concluded that by the end of the 18th century the per capita tax burden in Britain was about three times as large as it was in France (Mathias and O'Brien, 1976: 611).

Several scholars had also challenged the claims of rapacious taxation in China (Feuerwerker, 1984; Perkins, 1967; and Wang, 1974). Perkins, for instance, noted that 'Chinese sources are full of criticisms of taxes of all kinds' (Perkins, 1967: 481). However, rather than taking these criticisms as convincing evidence of unusually high tax rates, Perkins considered them in light of Chinese evidence on tax rates and revenue collected. He estimated that the land tax, the subject of much criticism, 'was on average at most 3 or 4 percent of the value of farm output' (Perkins, 1967: 481), and that at the end of the 19th century central government revenue was between 1 and 2 percent of GNP, which was 'an extraordinarily low figure' (Perkins 1967: 487). Perkins concluded: 'The image of the rapacious government attempting to crush commercial and industrial firms or to tax them to death through indifference is overdrawn' (Perkins, 1967: 491).

Other scholars have extended the analysis, temporally and geographically (Hoffman and Norberg, 2002; Karaman and Pamuk, 2010; Sng, 2014; Vries, 2015). Over the last two decades, work by a large number of scholars, using a variety of sources, have reached a similar conclusion: The leaders in representative government and economic growth - England and the Netherlands - were also the leaders in taxation (see Vries (2015) for a recent summary of the literature). The tax rates in England and the Netherlands in the 18th century 
have been estimated to be greater than France, Spain, China, and the Ottoman Empire. The recent work has not overturned Nef's contention that France taxed more heavily in 1640 , but it has found that British revenue rose rapidly after 1640 and that by 1700 per capita taxes in Britain exceeded those in France. The new evidence is consistent with the claims of Montesquieu and Smith that the British rates were the higher of the two when they wrote.

By 2009, it was possible for Dincecco (2009: 52) to state that 'It is a familiar fact that eighteenth-century absolutist regimes in France and Spain levied lower taxes per head than parliamentary-style ones in England or the United Provinces'. In response to the mounting evidence against the story of the rapacious despot, Rosenthal and Wong (2011: 168) declared: 'It is time to bury the despot'. Scholars who seek to explain the emergence of modern economic growth have now begun to place much greater emphasis on the role of state capacity, examining not just the level of taxes but how the revenue was collected and how it was spent (Dincecco, 2009; Johnson and Koyama, 2014; Rosenthal and Wong, 2011; Vries, 2015).

We have examined three cases in which attempts to incorporate the past into the study of institutions was shown to be inconsistent with the available evidence when subjected to a critical evaluation of the sources. There are other examples attempts to incorporate the past into economic analysis without sufficient attention the systematic study of the past. Several authors have challenged almost every element of the conventional wisdom regarding the Hawthorne experiments after re-examining primary sources (Gillespie, 1991; Hassard, 2012; Levitt and List, 2011; O'Connor, 1999). McKenna (2009) showed how the interpretation of Honda's strategy for entering the motorcycle market in the United States moved further and further away from the actual events in successive retellings of the story.

Each of these examples shows the importance of the historian's craft in the study of how institutions emerge and evolve. We are not suggesting that even the most careful analysis of sources will lead inevitably to 'the Truth'. Our interpretations of the past have to be pieced together from the sources that have been preserved. Even the most careful and accomplished historians can disagree about how to interpret the available evidence, but more attention to the historian's craft can help us to avoid using examples from the past the way the drunk uses the lamppost, for support rather than illumination. Without a critical approach to these sources, we run the risk of using legends rather than history to support our theories.

\section{Current empirical research and the historian's craft}

Source criticism is the heart of the historian's craft, and we have argued that it is essential for institutional economists who want to incorporate the past into their analysis in a fruitful way. We also want to argue that attention to 
how our evidence is created is useful even when we are not relying on the sort of primary sources, especially archival records that historians typically rely upon. Researchers who support their theories with evidence from surveys and experiments or large data sets can also benefit from a critical approach to their evidence. Just as people created and preserved archival documents, people report, collect, and record the data from surveys and experiments. People do not always have incentives to accurately report, collect, and record this evidence. Even when they wish to report accurately, they may have biases that influence their ability to do so.

Consider first survey data. In-person and telephone surveys often involve a principal-agent problem: the individuals collecting data may not have incentives to collect and report it accurately (Judge and Schechter, 2009; Philipson and Malani, 1999). The potential for falsification of survey data was recognized as early as the 1940s (Crespi, 1945). Schreiner et al. (1988: 491) define falsification as any instance in which the interviewer 'knowingly departs from current interviewing procedures to avoid interviewing, classifying and/or listing units'. There are non-trivial levels of falsification, even in well-established government surveys (Blasius and Friedrichs, 2012: 49). The U.S. Census Bureau, for instance, finds that between 3 and 5 percent of interviewers engage in some type of falsification, and that 72 percent of these interviewers entirely fabricated surveys (Biemer and Stokes, 1989: 25). Even if survey takers accurately record data, we must ask whether the person being surveyed was in a position to have knowledge of the events and whether they have any reason to misrepresent them (Waldman et al., 2012: 37)

Reliability may be an issue in survey data for other reasons. Some people appear to respond to surveys in ways that they believe will please the survey taker, even if the survey is anonymous and respondents have no other connection to the surveyor (Bertrand and Mullainathan, 2001: 68). People also exhibit systematic biases both in what they observe and in how they interpret their observations. For example, they fail to observe information when their attention has been directed toward something else (Chabris and Simons, 2010). They also tend to attribute outcomes to the agency of individuals rather than to random forces even when random forces are likely to have played a larger role in determining the outcome than individual actions (Weber et al., 2001).

Data created through experiments also need to be scrutinized. The actions of subjects in a lab may be influenced by the experimental setting, making it difficult to extend the results to situations outside the lab (Levitt and List, 2007). In addition, small differences in data collection methods in social science experiments can sometimes lead to significant differences in results (Doyen et al., 2012; and Pashler et al., 2012).

Finally, consider large data sets. The Nobel Memorial Prize winning economist Robert Fogel points to the quantitative analysis of large data sets as one of the defining features that separates modern 'scientific' research methods from 
traditional historical methods (Fogel, 1983). To Fogel, the traditional historian's reliance upon methods of authenticating evidence that were 'geared more to specific events involving specific individuals' is limiting (Fogel, 1983: 31). Yet many data sets are constructed from the historian's found evidence. Indeed, Fogel's own work on slavery was criticized by both economists and historians for insufficient attention to the historian's craft (David et al., 1976). Gutman and Sutch (1976), for instance, examined the claim that corporal punishment was used infrequently. They noted the claim was based on the journal of a single plantation owner, and that there were errors in the way that both the number of whippings and the number of slaves were estimated. This showed that the journal could be used as persuasive evidence that physical coercion was extensively used to control enslaved people. Examining each observation in a large data set may not be feasible, but statistical techniques can, for instance, be used to evaluate the likelihood of artificially constructed data (Nye and Moul, 2007) or biased samples (Bodenhorn et al., 2015).

\section{Conclusion}

We have argued that economists should give greater attention to history not just in terms of incorporating the past, but in terms of incorporating the historian's craft of source criticism. While we believe our argument is valid for all social scientists, we believe it is particularly important for those who study institutions. Debates about whether or not to incorporate history, in the sense of the past, are somewhat misleading. All evidence is necessarily historical in the sense that it provides information about events that occurred in the past. Even experiments and surveys are conducted before the analysis. But for social scientists who wish to understand the emergence and evolution of institutions, the need to study history goes well beyond the mere notion that all empirical work examines the past. Understanding why a particular institutional arrangement emerged and evolved and how it influenced the choices that people made necessarily involves sifting through the scattered bits and pieces of evidence that have been left over time. So, given that academics involved in the study of institutions must do history, they will benefit from learning to do it well.

We are not suggesting that economists go back to school and become historians. We are suggesting that, perhaps, The Historians Craft, Doing History, and Reliable Sources: A Primer on Historical Methods might begin to appear on economists shelves alongside Mostly Harmless Econometrics. We are suggesting that a critical approach to sources become a standard part of the research process, along with the choice of appropriate theoretical framework and method of analysis. We are suggesting, as Cipolla did, that we should pay attention to both critical evaluation of the evidence and the logic of arguments.

Our examples show that all arguments, whether built on analytical narrative or on econometric exercise, are only as robust as their sources are reliable. 
Regardless of whether the sources are primary or secondary, or whether they are qualitative or quantitative, researchers in search of an accurate account should routinely ask about the origin of each source. Who created it? Was the creator in a position to observe the phenomena being studied? Did the creator have incentives to accurately record the information? What biases did they have that may have influenced their perceptions?

Our examples also show the importance of using and understanding each source in light of all other available sources. Seeking out possibly contradictory sources is a necessary step in the evaluation of results, and is also useful in the development of hypotheses. Reading sources in context is essential in order to understand the point of view of the creator.

It seems likely that practicing and teaching methods of source interrogation will slow the pace of research: the additional searching, reading, and documenting sources takes time. But the benefits of practicing and teaching methods of source interrogation are potentially large for the discipline: We may make surer progress in answering the big questions about how institutions have inhibited or encouraged growth.

\section{References}

Acemoglu, D. and J. Robinson (2013), Why Nations Fail: The Origins of Power, Prosperity and Poverty, New York: Crown Publishers.

Appleby, J. O. and L. A. Hunt (1994), Telling the Truth About History, New York: Norton. Baptist, E. (2014), The Half Has Never Been Told: Slavery and the Making of American Capitalism, New York: Basic Books.

Berk, G. (1994), Alternative Tracks: The Constitution of American Industrial Order, 18651917, Baltimore: Johns Hopkins University Press.

Bertrand, M. and S. Mullainathan (2001), 'Do People Mean What They Say? Implications for Subjective Survey Data', American Economic Review, 9(2): 67-72.

Biemer, P. B. and S. L. Stokes (1989), 'The Optimal Design of Quality Control Samples to Detect Interviewer Cheating', Journal of Official Statistics, 5(1): 23-39.

Blanton, D. B. (2000), 'Drought as a Factor in the Jamestown Colony, 1607-1612', Historical Archaeology, 34(4): 74-81.

Blasius, J. and J. Friedrichs (2012), 'Faked interviews', in S. Salzborn, E. Davidov and J. Reinecke (eds.), Methods, Theories, and Empirical Application in the Social Sciences: Festschrift for Peter Schmidt, Wiesbaden: Springer VS.

Bloch, M. (1953), The Historian's Craft, New York: Vintage Books.

Bodenhorn, H., T. Guinnane and T. Mroz (2015), 'Sample Selection Bias and The "Industrialization Puzzle", NBER Working Paper No. 21249.

Boettke, P. J., C. J. Coyne and P. T. Leeson (2008), 'Institutional Stickiness and the New Development Economics', American Journal of Economics and Sociology, 67(2): 331358.

Boettke, P. J., C. J. Coyne and P. T. Leeson (2013), 'Comparative Historical Political Economy', Journal of Institutional Economics, 9(3): 285-301.

Brennan, G. and J. Buchanan, (1980), The Power to Tax: Analytical Foundations of a Fiscal Constitution, Cambridge: Cambridge University Press. 
Brundage, A. (2013), Going to the Sources: A Guide to Historical Research and Writing, Chichester: Wiley-Blackwell.

Burke, P. (1993), History and Social Theory, Ithaca: Cornell University Press.

Burnard, T. (2015), 'The Righteous Will Shine Like the Sun: Writing an Evocative History of Antebellum American Slavery, Slavery and Abolition, 36(1): 180-185.

Cabral, L. (2000), Introduction to Industrial Organization, Cambridge: MIT Press.

Casadesus-Masanell, R. and D. J. Spulber (2000), 'The Fable of Fisher Body', Journal of Law and Economics, 43(1): 67-104.

Chabris, C. and D. Simons (2010), The Invisible Gorilla: And other Ways our Intuitions Deceive us, New York: Crown Publishers.

Chamberlain, D. H. (1896), 'New Fashioned Receiverships, Harvard Law Review, 10(3): 139-149.

Chandler, A. D. (1984), 'The Emergence of Managerial Capitalism', Business History Review, 58(4): 473-503.

Chandler, A. D. and S. Salsbury (1971), Pierre S. du Pont and the making of the Modern Corporation, New York: Harper and Row.

Cipolla, C. (1992), Between Two Cultures: An Introduction to Economic History, New York: Norton.

Coase, R. (1937), 'The nature of the firm', Economica, 4(16): 386-405.

Coase, R. (1988), 'The Nature of the Firm: Influence', Journal of Law, Economics and Organization, 4(1): 33-47.

Coase, R. (2000), 'The Acquisition of Fisher Body by General Motors', Journal of Law and Economics, 43(1): 15-31.

Coase, R. (2006), The Conduct of Economics: The Example of Fisher Body and General Motors. Journal of Economics and Management Strategy, 15(2): 255-278.

Cohen, J. (2010), 'Private Capital, Public Credit and the Decline of American Railways, 1840-1940', The Journal of Transport History, 31(1): 42-68.

Cohen, D. and P. Mandler (2015), 'The History Manifesto: A Critique', American Historical Review, 120(2): 530-542.

Collingwood, R. G. (1946), The Idea of History, Oxford: Oxford University Press.

Crespi, I. P. (1945), 'The Cheater Problem in Polling', Public Opinion Quarterly, 9(4): 431455.

David, P., H. Gutman, R. Sutch, P. Temin and G. Wright (1976), Reckoning With Slavery: A Critical Study in the Quantitative History of American Negro Slavery, New York: Oxford University Press.

Davidson, J. W. and M. H. Lytle (2009), After the Fact: The Art of Historical Detection, New York: McGraw Hill.

De Long, J. B. and A. Shleifer, (1993), 'Princes and Merchants: European City Growth Before the Industrial Revolution', Journal of Law and Economics, 36(2): 671702.

Dincecco, M. (2009), 'Fiscal Centralization, Limited Government and Public Revenues in Europe, 1650-1913', Journal of Economic History, 69(1): 48-103.

Dobson, M. and B. Ziemann (eds.) (2009), Reading Primary Sources: The Interpretation of Texts from Nineteenth and Twentieth Century History, London: Routledge.

Doyen, S., O. Klein, C. Pichon and A. Cleeremans (2012), 'Behavioral Priming: It's All in the Mind, But Whose Mind?', PLoS One, 7(1): e29081.

Eichengreen, B. (2015), Hall of Mirrors: The Great Depression, the Great Recession, and the Uses and Misuses of History, New York: Oxford University Press. 
Elton, G. R. (1983), ‘Two Kinds of History', in R. W. Fogel and G. R. Elton (eds.), Which Road to the Past: Two Views of History, New Haven: Yale University Press.

Evans, R. J. (1999), In Defense of History, New York: Norton.

Feller, D. (2015), 'Standards of Accuracy in Historical Scholarship', published online at H-SHEAR https://networks.h-net.org/node/950/discussions/66981/standards-accuracy -historical-scholarship (last accessed 9 June 2015).

Feuerwerker, A. (1984), 'State and the Economy in Late Imperial China', Theory and Society, 13(3): 297-326.

Fogel, R. W. (1983), “'Scientific” History and Traditional History', in R. W. Fogel and G. R. Elton (eds.), Which Road to the Past: Two Views of History, New Haven: Yale University Press.

Franks, J. and O. Sussman (2005), 'Financial Innovations and Corporate Bankruptcy', Journal of Financial Intermediation, 14(3): 283-317.

Freeland, R. F. (2000), 'Creating Holdup Through Vertical Integration: Fisher Body Revisited', Journal of Law and Economics, 43(1): 33-66.

Gaddis, J. L. (2002), The Landscape of History: How Historians Map the Past, New York: Oxford University Press.

General Motors Corporation (1927), Eighteenth Annual Report of General Motors Corporation, Year ended December 31, 1926. http://www.library.upenn. edu/collections/lippincott/corprpts/gm/gm1926.pdf (last accessed November 9, 2014).

Gillespie, R. (1991), Manufacturing Knowledge: A History of the Hawthorne Experiments, Cambridge: Cambridge University Press.

Ginzburg, C. (2013), Clues, Myths, and the Historical Method, in J. Tedeschi and A. C. Tedeschi (eds.), Baltimore: Johns Hopkins University Press.

Guldi, J. and D. Armitage (2014), The History Manifesto, Cambridge: Cambridge University Press.

Gutman, H. and R. Sutch (1976), 'Sambo Makes Good, or Were Slaves Imbued With the Protestant Work Ethic?', in David et al (eds.), Reckoning with Slavery: A Critical Study in the Quantitative History of American Negro Slavery, New York: Oxford University Press.

Hansen, B. A. (2000), 'Corporate Reorganization and the People's Welfare: The Wabash Receivership Reconsidered', Business History Review, 74(3): 377-405.

Hansen, B. A. (2009), Institutions, Entrepreneurs, and American Economic History: How the Farmers' Loan and Trust Company Shaped the Laws of Business from 1822 to 1929, New York: Palgrave Macmillan.

Hassard, J. S. (2012), 'Rethinking the Hawthorne Studies: The Western Electric Research in its Social, Political and Historical Context', Human Relations, 65(11): 14311461.

Helper, S., J. P. MacDuffie and C. Sabel (2000), 'Pragmatic Collaborations: Advancing Knowledge While Controlling Opportunism', Industrial and Corporate Change, 9(3): 443-488.

Hexter, J. H. (1971), Doing History, Bloomington: Indiana University Press.

Hodgson, G. M. (2001), How Economics Forgot History: The Problem of Historical Specificity in Social Science, London: Routledge.

Hodgson, G. M. (2009), 'The Great Crash and the Reform of Economics', Cambridge Journal of Economics, 33: 1205-1221.

Hoffer, P. C. (2004), Past Imperfect: Facts, Fiction, Fraud- American History from Bancroft and Parkman to Ambrose, Bellesiles, Ellis, and Goodwin, New York: Public Affairs. 
Hoffer, P. C. (2008), The Historians' Paradox: The Study of History in Our Time, New York: New York University Press.

Hoffman, P. and K. Norberg (2002), Fiscal Crises, Liberty, and Representative Government, 1450-1789, Palo Alto: Stanford University Press.

Howell, M. and W. Prevenier (2001), Reliable Sources: An Introduction to Historical Methods, Ithaca: Cornell University Press.

Johnson, N. D. and M. Koyama (2014), 'Tax Farming and the Origins of State Capacity in England and France', Explorations in Economic History, 51(1): 1-20.

Jones, E. (1981), The European Miracle: Environments, Economies, and Geopolitics in the History of Europe and Asia, Cambridge: Cambridge University Press.

Judge, G. and L. Schechter (2009), 'Detecting Problems in Survey Data using Benford's Law', Journal of Human Resources, 44(1): 1-24.

Karaman, K.K. and S. Pamuk (2010), 'Ottoman State Finances in European Perspective', Journal of Economic History, 70(3): 593-629.

Klein, B. (1988), 'Vertical Integration as Organizational Ownership: The Fisher Body-General Motors Relationship Revisited', Journal of Law Economics and Organization, 4(1): 199-213.

Klein, B. (2000), 'Fisher-General Motors and the Nature of the Firm', Journal of Law and Economics, 43(1): 105-142.

Klein, B. (2007), 'Economic Lessons of Fisher Body-General Motors', International Journal of the Economics of Business, 14(1): 1-36.

Klein, B. (2008), 'The Enforceability of the GM-Fisher Body Contract: Comment on Goldberg', Industrial and Corporate Change, 17(5): 1085-1096.

Klein, B., R. Crawford and A. Alchian (1978), 'Vertical Integration, Appropriable Rents, and the Competitive Contracting Process', Journal of Law and Economics, 21(2): 297-326.

Koyama, M. (2015), 'Review of The History Manifesto by J. Guldi and D. Armitage', Journal of Economic History, 75(2): 584-587.

Landes, D. (2006), 'Why Europe and the West? Why not China?', Journal of Economic Perspectives, 20(2): 3-22.

Levitt, S. and J. List (2007), 'What Do Laboratory Experiments Measuring Social Preferences Tell Us About the Real World?', Journal of Economic Perspectives, 21(2): 153-174.

Levitt, S. and J. List (2011), 'Was There Really a Hawthorne Effect at the Hawthorne plant? An Analysis of the Original Illumination Experiments', American Economic Journal: Applied Economics, 3(1): 224-238.

Lipartito, K. (2014), 'Historical Sources and Data', in M. Bucheli and R. D. Wadhwani (eds.), Organizations in Time: History, Theory, and Methods, Oxford: Oxford University Press.

Manne, H. (1958), 'The Perplexing Du Pont Case: Additional Confusion in the Law of Mergers', University of Pennsylvania Law Review, 106(3): 385-412.

Marius, R. and M. Page (2002), A Short Guide to Writing About History (4th edn), New York: Longman.

Martin, A. (1974), 'Railroads and the Equity Receivership: An Essay on Institutional Change', Journal of Economic History, 34(3): 685-709.

Mathias, P. and P. O'Brien (1976), 'Taxation in Britain and France, 1715-1810. A Comparison of the Social and Economic Incidence of Taxes Collected for the Central Governments', Journal of European Economic History, 5(4): 601-650.

McCloskey, D (1976), 'Does the Past Have Useful Economics?', Journal of Economic Literature, 14(2): 434-461. 
McKenna, C. (2006), 'Writing the Ghost Writer Back In: Alfred Sloan, Alfred Chandler, John McDonald and the Intellectual Origins of Corporate Strategy', Management and Organizational History, 1(2): 107-126.

McKenna, C. (2009), 'Mementos: Looking Backwards at the Honda Motorcycle Case', in S. H. Clarke, N. Lamoreaux and S. W. Usselman (eds.), The Challenge of Remaining Innovative: Insights from Twentieth Century American Business, Stanford: Stanford University Press.

Megill, A (2007), Historical Knowledge, Historical Error: A Contemporary Guide to Practice, Chicago: University of Chicago Press.

Milgrom, P. and J. Roberts (1992), Economics, Organization and Management, Englewood Cliffs: Prentice Hall.

Montesquieu, C. (1989), The Spirit of the Laws, in A. M. Cohler, B. C. Miller and H. Stone (eds.), Cambridge: Cambridge University Press.

Nef, J. (1957), Industry and Government in France and England, 1540-1640, Ithaca: Cornell University Press.

Nevins, A. (1962), The Gateway to History, Garden City, NY: Anchor Books.

North, D. C. (1981), Structure and Change in Economic History, New York: W.W. Norton.

North, D. C. and P. R. Thomas (1973), The Rise of the Western World: A New Economic History, Cambridge: Cambridge University Press.

Novick, P. (1988), That Noble Dream: The 'Objectivity Question' and the American Historical Profession, Cambridge: Cambridge University Press.

Nunn, N. (2009), 'The Importance of History for Economic Development', Annual Review of Economics, 1(1): 65-92.

Nye, J. and C. Moul (2007), 'The Political Economy of Numbers: On the Application of Benford's Law to International Macroeconomic Statistics', B.E. Journal of Macroeconomics, 7(1): article 17.

O’Connor, E. (1999), 'The Politics of Management Thought: A Case Study of the Harvard Business School and the Human Relations School', Academy of Management Review, 24(1): 117-131.

Ogilvie, S. and A. W. Carus (2014), 'Institutions and Economic Growth in Historical Perspective', in P. Aghion and S. N. Durlauf (eds.), Handbook of Economic Growth: Volume 2A. Amsterdam: Elsevier.

Olson, M. (1991), 'Autocracy, Democracy and Prosperity', in R. Zeckhauser (ed.), Strategy and Choice, Cambridge: MIT Press.

Olson, M. (1993), 'Dictatorship, Democracy, and Development', American Political Science Review, 87(3): 567-576.

O’Rourke, K. H. (2013), 'Why Economics Needs Economic History', http://www.voxeu.org/ article/why-economics-needs-economic-history [accessed 1 September 2015].

Pashler, H., N. Coburn and C. R. Harris (2012), 'Priming of Social Distance? Failure to Replicate Effects on Social and Food Judgments', PLoS One 7: e45210.

Perkins, D. (1967), 'Government as an Obstacle to Industrialization: The Case of NineteenthCentury China', Journal of Economic History, 27(4): 478-492.

Perrow, C. (2002), Organizing America: Wealth, Power and the Origins of Corporate Capitalism, Princeton: Princeton University Press.

Peterson, J. (2013), 'Economics Education After the Crisis: Pluralism, History and Institutions', Journal of Economic Issues, 47(2): 401-410.

Philipson, T. and A. Malani (1999), 'Measurement Errors: A Principal Investigator-Agent Approach', Journal of Econometrics, 91(2): 273-298. 
Piketty, T. (2014), Capital in the Twenty-First Century, Cambridge: Harvard University Press. Rosenthal, J. L. and R. B. Wong (2011), Before and Beyond Divergence: the Politics of Economic Change in China and Europe, Cambridge: Harvard University Press.

Roy, W. G. (1997), Socializing Capital: The Rise of the Large Industrial Corporation in America, Princeton: Princeton University Press.

Schreiner, I., K. Pennie and J. Newbrough (1988), 'Interviewer Falsification in Census Bureau Surveys', Proceedings of the American Statistical Association, Survey Research Methods Section, pp. 491-496. Alexandria, Virginia: American Statistical Association.

Shiller, R. (2010), 'How should the financial crisis change how we teach economics?', Journal of Economic Education, 41(4): 403-409.

Sloan, A. P. (1963), My Years With General Motors, New York: Macfadden Books.

Smith, A. (1976), An Inquiry into the Nature and Causes of the Wealth of Nations, in E. Cannan (ed.), Chicago: University of Chicago Press.

Sng, T. H. (2014), 'Size and Dynastic Decline: the Principal Agent Problem in Late Imperial China', Explorations in Economic History, 54:107-127.

Swain, H. H. (1898), 'Economic Aspects of Railroad Receiverships', Economic Studies, 3(2): 53-161.

Temin, P. (2014), 'The Rise and Fall of Economic History at MIT', History of Political Economy, 46(suppl. 1): 337-350.

Toulmin, S. (2003), The Uses of Argument: Updated Edition, Cambridge: Cambridge University Press.

Van Bavel, B. (2015), 'History as a Laboratory to Better Understand the Formation of Institutions', Journal of Institutional Economics, 11(1): 69-91.

Vries, P. (2015), State, Economy and The Great Divergence: Great Britain and China, 1680s1850s, London: Bloomsbury.

Waldman, D. A., M.S. de Luque and D. Wang (2012), 'What Can We Really Learn About Management Practices Across Firms and Countries?', Academy of Management Perspectives, 25(1): 34-40.

Wang, Y. (1974), Land Taxation in Imperial China, 1750-1911, Cambridge: Harvard University Press.

Weber, R., C. Camerer and Y. Rottenstreich (2001), 'The Illusion of Leadership: Misattribution of Cause in Coordination Games', Organization Science, 12(5): 582598.

Williamson, O.E. (1971), 'The Vertical Integration of Production: Market Failure Considerations', American Economic Review, 61(2): 12-123.

Winks, R. W. (1968), The Historian as Detective: Essays on Evidence, New York: Harper and Row. 